\title{
MYCOBIOTA ON COMMON WHEAT (Triticum aestivum) AND SPELT (Triticum aestivum ssp. spelta) GRAINS FROM THE REGION OF VOJVODINA IN 2015
}

\author{
Jelena A. Krulj ${ }^{* 1}$, Aleksandra S. Bočarov Stančić ${ }^{2}$, Saša Z. Krstović ${ }^{3}$, Igor M. Jajić ${ }^{3}$, Jovana S. Kojić ${ }^{1}$, \\ Ana M. Vidaković ${ }^{4}$, Marija I. Bodroža Solarov ${ }^{1}$ \\ ${ }^{1}$ University of Novi Sad, Institute of Food Technology, 21000 Novi Sad, \\ Bulevar cara Lazara 1, Serbia \\ ${ }^{2}$ Institute for Science Application in Agriculture, 11000 Belgrade, \\ Bulevar despota Stefana 68B, Serbia \\ ${ }^{3}$ University of Novi Sad, Faculty of Agriculture, 21000 Novi Sad, \\ Trg Dositeja Obradovića 8, Serbia \\ ${ }^{4}$ University of Novi Sad, Faculty of Technology, 21000 Novi Sad, \\ Bulevar cara Lazara 1, Serbia
}

\author{
${ }^{*}$ Corresponding author: \\ Phone: +381214853798 \\ E-mail address: jelena.krulj@fins.uns.ac.rs
}

\begin{abstract}
The incidence of mycobiota on common wheat (Triticum aestivum) and spelt (Triticum aestivum ssp. spelta) samples, collected during the harvest in 2015 , was investigated. The obtained results showed that more genera of mycobiota were isolated from the common wheat grains than from the spelt grains. The most frequently isolated species from common wheat grains belonged to genus Alternaria (41.7\%), followed by Fusarium (15.2\%), while the incidence of this mycobiota on the spelt grains were $32.4 \%$ and $10.4 \%$, respectively. Aspergillus flavus was identified in $40.0 \%$ wheat samples, with the incidence of $2.0 \%$. Additionally, this study was undertaken in respect of the occurrence and toxigenic potential of $A$. flavus isolates from these small grain cereals. A simple screening method was applied to determine toxigenic profiles (aflatoxins production) of $A$. flavus isolates from common wheat. The results revealed the importance of precise investigation of mycobiota distribution on common wheat and spelt grains, and especially the investigation of toxigenic potential of $A$. flavus.
\end{abstract}

Key words: mycobiota, common wheat, spelt, Aspergillus flavus, toxigenic potential

\section{INTRODUCTION}

Wheat, as one of the most important grain crops in the world, can be easily grown in different climatic regions. Accordingly, wheat is susceptible to infections of many mycotoxin-producing mycobiota, such as Fusarium, Aspergillus, Penicillium and Alternaria (Alkadri et al., 2014). Fungal contamination of cereal crops causes yield losses, lower grain quality and results in the accumulation of mycotoxins in significant concentrations (Šarić et al., 2008).
Mycotoxins may lead to health disorders due to a variety of their toxic effects on humans and animals. Wheat-based feed and food can be contaminated with mycotoxins in any stage of processing cycle: primary production, processing, transport and trading, i.e. "from field to fork" (Oliveira et al., 2014).

Spelt is an ancient wheat species currently receiving renewed interest due to its prohealth properties and suitability for organic 
production (Kurowski and Wysocka, 2009; Lacko-Bartošová et al., 2010). It is considered that spelt has a higher nutritional value than common wheat, but also higher resistance to unfavourable environmental factors including resistance to pathogens (Suchowilska et al., 2010; Solarska et al., 2012). Bodroža-Solarov et al. (2010) and Vučković et al. (2013) confirm that spelt hulls have protective effect and can reduce fungal and toxic contamination of spelt kernels, compared to common wheat kernels. Hard spelt hulls may pose an effective barrier for mycelial filaments of mycobiota.

The importance of species of the genus Aspergillus can be considered on the basis of their toxins that may have negative impact on food safety and quality (Gibbson, 2012). Currently, the most significant worldwide mycotoxins produced by Aspergillus spp. are aflatoxins, potentially carcinogenic and teratogenic metabolons for both humans and animals (Hedayati et al., 2007). Aspergillus species commonly occur in agricultural products in warm, arid, semi-arid and tropical regions where temperature and humidity conditions are suitable for the growth of mycobiota and production of toxins (Cotty and Jaime-Garcia, 2007). Data on the occurrence of Aspergillus species in Serbia indicate their generally low frequency and incidence in wheat grain (Lević et al., 2012a). Natural occurrences of aflatoxins are scarce in the agroecological conditions of Serbia, but there has recently been an intensified presence of these mycotoxins in maize (Kos et al., 2014). Lević et al. (2013) investigated the frequency and incidence of $A s-$ pergillus flavus in kernels of soybean, maize, barley, sunflower and wheat in the period 2008-2012. An exceptionally high emergence of Aspergillus species occured in 2012. Hot and dry weather with prolonged drought during spring and summer have great influence on a contamination of grains with aflatoxins. If the temperature becomes much higher with more frequent drought periods, it can lead to more frequent occurrence of Aspergillus species and their toxins in plant species in Serbia and other parts of the world. The aim of this investigation was to determine species compositions and abundance of mycobiota colonizing grains of winter $T$. aestivum and $T$. aestivum ssp. spelta, with a special focus on Aspergillus flavus. The present study was also carried out in order to isolate and identify the potentially aflatoxigenic $A$. flavus in wheat.

\section{MATERIALS AND METHODS}

\section{Fungal isolation and determination}

The study was conducted on grain samples of $T$. aestivum and $T$. aestivum ssp. spelta collected during the wheat harvest period (June-July, 2015) in the region of Vojvodina (Northern Province of Serbia).

Isolation and identification of fungi was performed according to Lević et al., (2012a). A hundred of common wheat kernels and fifty spelt kernels were taken randomly from each sample, being surface disinfected with $1 \%$ sodium hypochlorite for 5 minutes, and then rinsed three times with sterilized distilled water. The grains were dried on sterilized filter paper and placed on DG 18 - Dichloran 18\% Glycerol agar (Himedia, India) media in five replicates for each sample. Each replicate contained 20 common wheat kernels and 10 spelt kernels per Petri dish. Plates were incubated at $25^{\circ} \mathrm{C}$ for 7 days in darkness. Cultures obtained from growing colonies on DG 18 were transferred individually on PDA - Potato Dextrose Agar (Himedia, India) for futher purification and identifycation. In order to determine individual species of mycobiota reliably, fragments of the colonies developed on PDA were transferred to SNA (Syntetic Nutrition Agar) (Nirenberg and O' Donnell, 1998), Aspergillus flavus and parasiticus agar AFPA (Rodrigues et al., 2007) and Czapek's agar (CZA). All cultivation, except on AFPA, were performed 7-14 days at $25{ }^{\circ} \mathrm{C}$. On AFPA, selective medium for the identification of species from $A$. flavus group, cultivations were done at $30{ }^{\circ} \mathrm{C}$ for 3 days. Determinations of other fungal genera and species were done according to the following authors: Ellis (1971), Domsh et al. (1980), Travassos and Lioyd (1980), Nelson et al. (1983) and Samson and van Reenen-Hoekstra (1988). The frequency $(F)$ and incidence (I) of mycobiota were calculated according to Lević et al. $(2012 a): F(\%)=[$ Number of infected sam- 
ples/Total number of samples] x 100; I (\%) $=[$ Number of infected kernels in the sample/Total number of kernels in the same sample] x 100.

\section{Screening of toxin production}

The Aspergillus isolates were cultivated on the standard yeast extract-sucrose agar (YESA - $2 \%$ yeast extract, $15 \%$ sucrose and $2 \%$ agar, $\mathrm{pH}$ 6.5, Samson and van Reenen-Hoekstra, 1988). The toxigenic potential of the isolates was determined after 14,21 and 28 days of cultivation at $25{ }^{\circ} \mathrm{C}$. The agar plugs were cut out of the colony centre with a sterile metal borer (diameter $6 \mathrm{~mm}$ ), removed from the agar plate and placed with a sterile needle or tweezers in a sterilized Petri dish with a mycelial side up. The circular plugs were wetted with 10-20 $\mu$ l of chloroform/methanol $(2: 1 \mathrm{v} / \mathrm{v})$ and after few seconds the rapidly extracted mycelial side was gently applied against the TLC plate (Alugram SIL G/UV 254, Macherey-Nagel) with sterile tweezers. After drying the application spot, another one of the same colony was applied nearby, together with $30 \mu$ of the working standard of the tested mycotoxin (internal standard). The thin-layer chromatography was performed in saturated tanks with toluene/ethyl acetate/formic acid developing solvent $(90+10 \mathrm{v} / \mathrm{v})$. After developing plates and air drying in a dark fume extractor, the plates were examined under long wave UV light (366 nm) (BočarovStančić et al., 2009a).

\section{RESULTS AND DISCUSION}

\section{Mycobiota on wheat grain}

The presence of fungal genera in grain samples of $T$. aestivum and $T$. aestivum ssp. spelta was investigated during the wheat harvest period in 2015. Mycological investigations showed the presence of 12 fungal genera on common wheat and 5 genera on spelt grains. The mycobiota isolated from the common wheat grains are shown in Table 1. Arthrinium sp., Aspergillus spp., Cladosporium spp., Gilmaniella sp., Nigrospora sp., Sporotrix spp., Trichocladium sp. were genera that were isolated from the common wheat grains, but not from the spelt (Table 2).

Table 1.

Frequency and incidence of fungal genera on the common wheat grains

\begin{tabular}{lcc}
\hline Fungal genera & Frequency (\%) & $\begin{array}{c}\text { Incidence (\%) } \\
\text { Mean value }\end{array}$ \\
\hline Alternaria spp. & 100.0 & 41.7 \\
Arthrinium phaeospermum (Corda) M.B. Ellis & 20.0 & 1.0 \\
Aspergillus flavus Link ex Fr. & 40.0 & 2.0 \\
A. fumigatus Fres. & 20.0 & 1.0 \\
A. nidulans G Winter & 20.0 & 1.0 \\
A. niger van Tieghem & 20.0 & 1.0 \\
Cladosporium spp. & 80.0 & 7.7 \\
Dematiaceous Hyphomycetes (non-sporulating) & 100.0 & 16.2 \\
Fusarium graminearum Schwabe & 100.0 & 13.2 \\
F. poae (Peck) Wolenw. & 20.0 & 1.0 \\
F. sporotrichioides Sherb. & 20.0 & 1.0 \\
Gilmaniella humicola G.L. Barron & 20.0 & 2.0 \\
Nigrospora oryzae (Berk and Br.) Petch. & 40.0 & 1.5 \\
Penicillium spp. & 20.0 & 3.0 \\
Sporotrix sp. & 20.0 & 1.0 \\
Stemphylium spp. & 20.0 & 17.0 \\
Trichocladium pyriforme Dixon & 20.0 & 2.0 \\
Ulocladium spp. & 40.0 & 6.5 \\
\hline
\end{tabular}

Table 2.

Frequency and incidence of fungal genera in the spelt grains

\begin{tabular}{lcc}
\hline Fungal genera & Frequency (\%) & $\begin{array}{c}\text { Incidence (\%) } \\
\text { Mean value }\end{array}$ \\
\hline Alternaria spp. & 100.0 & 32.4 \\
Dematiaceous Hyphomycetes (non-sporulating) & 100.0 & 22.0 \\
Fusarium graminearum Schwabe & 100.0 & 10.4 \\
Penicillium spp. & 40.0 & 2.0 \\
Stemphylium spp. & 20.0 & 7.0 \\
Ulocladium spp. & 20.0 & 8.0 \\
\hline
\end{tabular}




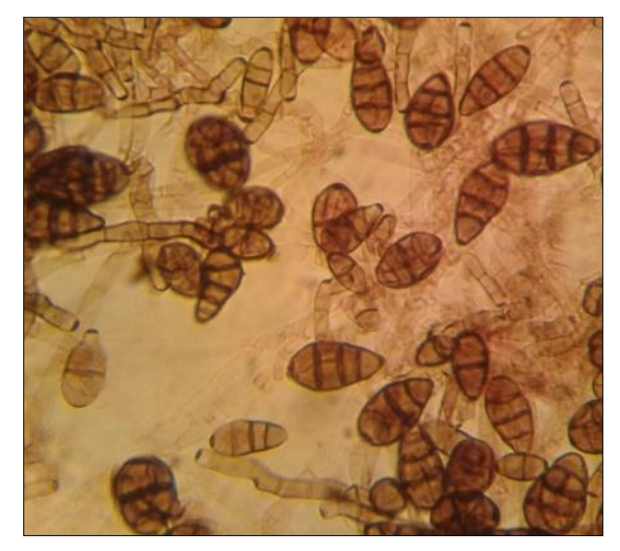

Figure 1. Alternaria spp. (PDA, $25^{\circ} \mathrm{C}, 7$ days)

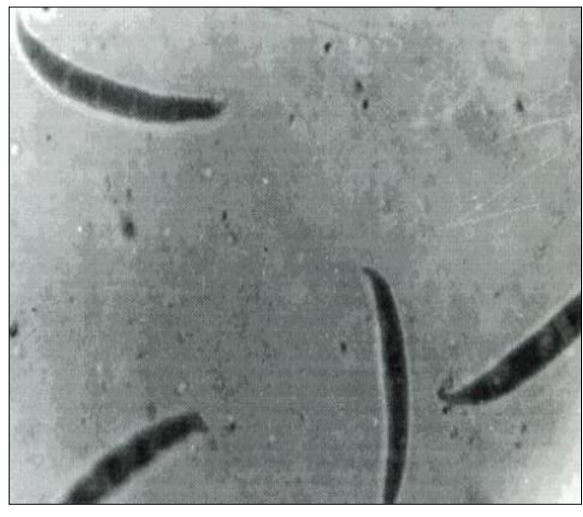

a)

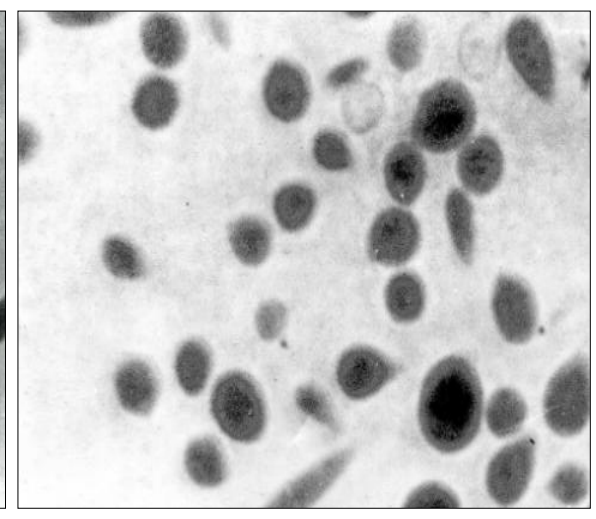

b)

Figure 2. Microscopic view of macro and micro conidia (SNA, $25^{\circ} \mathrm{C}, 7$ days)

a) Fusarium graminearum b) Fusarium poae

Table 2. presents infection frequencies and incidence of mycobiota in the spelt grain samples. More genera of mycobiota were isolated from the common wheat than from the spelt grains. Due to a higher stalk and hard adherent hulls, spelt is one of the cereals less infected by mycobiota (Solarska et al., 2012). Hulls might be considered as physical barriers that protect kernels from pathogens (Bavec et al., 2006). This might explain why more genera of mycobiota were isolated from the common wheat grains.

Genus Alternaria showed the highest frequency $(100.0 \%)$ on the common wheat grains (mainly $A$. alternata (Fr.) Keissl.) as well as on the spelt grains (mainly $A$. tenuissima (Nees) Wiltshire) with the incidence of $41.7 \%$ and $32.4 \%$, respectively.

Both mycobiota are typical saprophytic cosmopolitan opportunistic plant pathogens that cause grain discoloration including developing of black spots (Šarić et al., 2008;
Kurovski and Wysoska, 2009).

According to Balaž et al., (2003), Stanković et al., (2007), Krnjaja et al., (2011), the presence of genus Alternaria (Figure 1) varies depending on agroecological conditions in Serbia for the relevant year of examination. The weather conditions in 2015 were characterized by moderate conditions and near-average precipitation across most of Serbia. Mean air temperature was in the categories of normal (Republic Hydrometeorological Service of Serbia, 2015). According to the results of other researchers of Alternaria mycobiota in Serbia, species that are usually detected on common wheat were $A$. alternata and $A$. logipes (Ivanović et al., 2001), while prevalent species on spelt wheat were $A$. alternata and $A$. tenuissima (Vučković et al., 2012), although $A$. infectoria was also observed (Đisalov et al., 2015). Under favourable conditions these species can produce different mycotoxins (alter- 
nariol, tenuazonic acid etc.) harmful to human and animal health (Vučković et al., 2013; Janjić-Hajnal et al., 2015).

According to some authors, the presence of Fusarium spp. (mainly F. oxysporum) have considerable importance because it is the most often (found in about $45 \%$ samples) determined fungal genus on wheat in Serbia (Stojanović et al., 2005b). On the other hand Krnjaja et al. (2011) observe that other Fusarium species - $F$. graminearum (Figure 2a) and $F$. poae (Figure 2b) occured in winter wheat in a great abundance. In our investigation (Tables 1 and 2), the predominant fusaria on wheat grains (frequency $100.0 \%$, incidence $13.2 \%$ ) was also $F$. graminearum $(96.0 \%)$, while other two identified species $F$. poae and $F$. sporotrichioides amounted to only $20.0 \%$ frequency and $1.0 \%$ incidence (Table 1). All samples of spelt grains were also colonized by $F$. graminearum, but the incidence of this mycobiota was lower than that on the wheat grains (Table 2). Although identified Fusarium species are weak cereal pathogens (with the exception of $F$. graminearum), all three of them can cause serious health disorders in humans and animals as producers of several mycotoxins (Bočarov-Stančić et al., 2007; BočarovStančić et al., 2009b).

Although the mycobiota of the genus Cladosporium had a high frequency $(80.0 \%)$, their incidence was rather low $(7.7 \%)$ on the common wheat (Table 1). Representatives of this genus, together with Nigrospora oryzae, are common mycobiota of wheat grain all over the world (Fahrunnisa et al., 2006; Lević et al., 2012b).

Unlike non-sporulating Dematiaceous $\mathrm{Hy}$ phomycetes (frequency $100.0 \%$, incidence $16.2-22.0 \%$ ), the sporulating ones (Gilmaniella humicola, Trichocladium pyriforme, Stemphylium spp. and Ulocladium spp.) were less frequently identified (20.0$40.0 \%)$ on both tested small grain cereals (Tables 1 and 2).

The potentially toxigenic species of Aspergillus and Penicillium genera had very low incidence (2.0-3.0\%) and did not show too too high frequency (Tables 1 and 2).
The incidence of Arthrinium phaeospermum and Sporotrix sp. was less prominent and amounted to only $1.0 \%$ (Table 1 ). A. phaeospermum is common mycobiota in both soft and durum wheat grains (Abdullah and Atroshi, 2014) as well as in winter spelt grains (Kurovski and Wysocka, 2009). Sporotrix sp. was previously found on wheat rachides in Serbia (Lević et al., $2012 b$ ) but not on wheat grains.

The results of microbiological analyses of wheat grain samples are in accordance with previously published results of other Serbian authors (Stanković et al., 2007; Krnjaja et al., 2011; Lević et al., 2012b).

\section{Occurrance of Aspergillus flavus}

Aspergillus flavus (Figure 3 ) is mostly considered as a storage fungus, but under specific agroecological conditions it might cause high infection frequencies of grains in the field (Lević et al., 2013). In this study, a medium frequency $(40.0 \%)$ and a low incidence $(2.0 \%)$ of $A$. flavus on wheat samples was observed (Table 1). Similar occurrence of genus Aspergillus (1.4\%) on wheat was noted in the investigation of Stojanović et al. (2005a).

The type of isolation media for mycobiota has a special importance for the identification of $A$. flavus. AFPA (Aspergillus flavus and parasiticus agar) and Czapek's agar (CZA) were used as selective media for the identification of strains from $A$. flavus group. These media are suitable for rapid detection and enumeration of $A$. flavus. Colonies of $A$. flavus in AFPA, incubated at $30{ }^{\circ} \mathrm{C}$ for 3 days are shown in Figure 4. The distinguishing between Aspergillus spp. is based on the development of characteristic orange colour on the reverse of the colonies cultivated on the AFPA plates (Rodrigues et al., 2007).

\section{The toxigenic potential of Aspergillus flavus}

The most important mycotoxins produced by mycobiota of the genus Aspergillus are aflatoxins, classified as primary carcinogenic compounds by the International Agency for Research on Cancer (IARC, 2002). Aflatoxin B1 (AFB1) is the most frequent and the most potent toxin. 


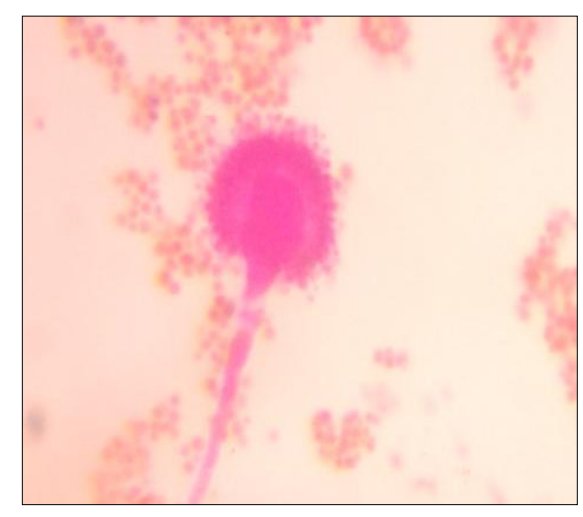

Figure 3. Aspergillus flavus (CZA, $25^{\circ} \mathrm{C}, 7$ days)
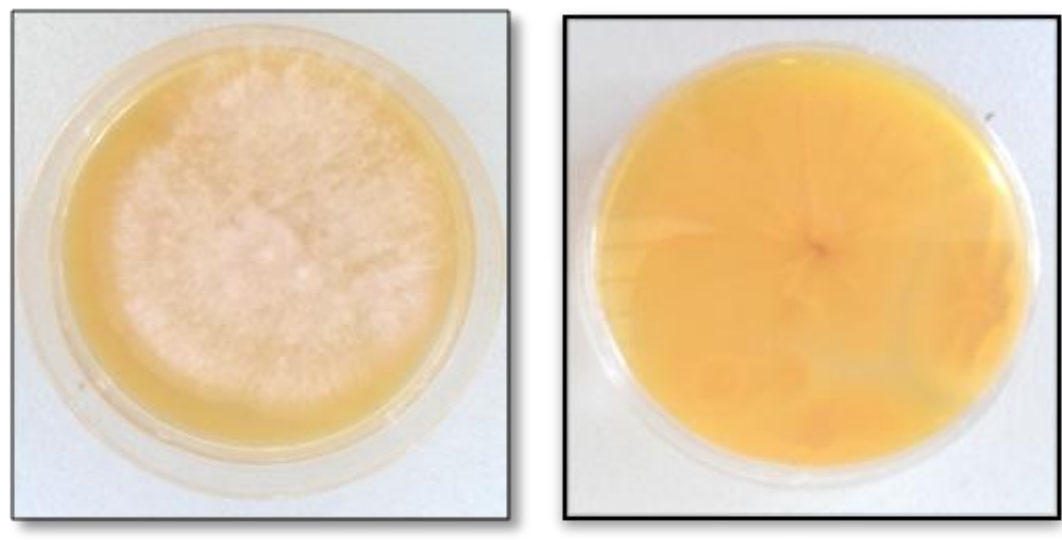

Figure 4. A. flavus isolate grown on $A$. flavus and parasiticus agar (AFPA) $\left(30^{\circ} \mathrm{C}, 3\right.$ days)

Table 3.

Production of aflatoxin B1 by $A$. flavus isolates on YESA at $25^{\circ} \mathrm{C}$

\begin{tabular}{llll}
\hline \multirow{2}{*}{ Isolates designation } & \multicolumn{4}{c}{ The toxigenic potential of Aspergillus flavus } \\
\cline { 2 - 4 } & $\mathbf{1 4}$ days & $\mathbf{2 1}$ days & $\mathbf{2 8}$ days \\
\hline $1_{2}$ & + & + & - \\
73 & - & - & - \\
$20_{1}$ & + & + & - \\
$20_{2}$ & - & - & - \\
\hline "“- low intensity of biosynthesis; ,"“- no biosynthesis & &
\end{tabular}

Potential for the biosynthesis of AFB1 was investigated in $4 \mathrm{~A}$. flavus isolates from the common wheat. Unlike the common wheat, $A$. flavus was not found on the samples of spelt wheat. The results gained with TLC showed that two isolates of $A$. flavus $\left(1_{2}\right.$ and $\left.20_{1}\right)$ had toxigenic potential for the AFB1 biosynthesis after 14 and 21 days of cultivation on YESA at $25{ }^{\circ} \mathrm{C}$ (Table 3). The AFB1 was not detected in any isolates after 28 days of cultivation.

These results point out the necessity for monitoring the toxigenic potential and emergence of $A$. flavus in the field and al- so during storage and processing of small grain cereals. As a consequence of climate changes, stressful weather conditions (high temperatures and drought) may lead to production of aflatoxins, which can be associated with human and animal health risk.

\section{CONCLUSION}

The grain samples of common wheat were colonized by a higher number of fungal genera (12), then the spelt grain samples (5). Although the frequency of the determined mycobiota was similar on the com- 
mon wheat grains and the spelt grains, there was a significant difference in their incidence. The present study shows the necessity for continuous mycological and mycotoxicological control of small grain, after harvesting, warehousing and processing, as one of the main steps in the evaluation of quality and health status of grains related to food safety. Changes in climatic conditions may lead to changes in mycobiota and mycotoxins commonly present in European samples of small grains.

\section{ACKNOWLEDGEMENTS}

This paper is a result of the research within the project III 46005 „New products based on cereals and pseudo-cereals from organic production", funded by the Ministry of Education, Science and Technological Development, Republic of Serbia.

\section{REFERENCES}

1. Abdullah, S.K., Atroshi, H.I. (2014). New records of fungi on wheat grains from Iraq. Journal of University of Zakho, 2 (A), 256-265.

2. Alkadri, D., Rubert, J., Prodi, A., Pisi, A., Mañes, J., Soler, C. (2014). Natural co-occurrence of mycotoxins in wheat grains from Italy and Syria. Food Chemistry, 157, 111-118.

3. Balaž, F., Bagi, F., Škrinjar, M.R., Stojšin, V. (2003). Mikopopulacija semena strnih žita u 2002. godini. Žito-hleb, 30 (4-5), 149-155.

4. Bavec, F., Rantaša, J., Mlakar, S., Grobelnik, J.M., Bavec, M. (2006). Yield performance in spelt regarding to hulled and dehulled seeds sown at different rates and dates. Bibliotheca Fragmenta Agronomica, 11, 43-44.

5. Bočarov-Stančić, A., Lević, J., Stanković, S., Krnjaja, V., Kovačević, T., Tančić, S. (2007). The toxigenic potential of Fusarium poae originated from wheat. Proceedings for Natural Sciences, Matica srpska Novi Sad, 113, 113-123.

6. Bočarov-Stančić, A., Lević, J., Dimić, G., Stanković, S., Salma, N. (2009a). Investigation of toxigenic potential of fungal species by the use of simple screening method. Proceedings for Natural Sciences, Matica srpska Novi Sad, 108, 59-67.

7. Bočarov-Stančić, A., Lević, J., Stanković, S, Stanišić, M., Bilek, S. (2009b). Dynamics of deoxynivalenol and zearalenone production by Fusarium graminearum under laboratory conditions. Proceedings for Natural Sciences, Matica srpska, Novi Sad, 116, 1524,

8. Bodroža-Solarov, M., Balaž, F., Bagi, F., Filipčev, B., Šimurina, O., Mastilović, J. (2010). Effect of hulls on grain mould infestation in Triticum aestivum ssp. spelta from organic trial. $45^{\text {th }}$ Croatian and $5^{\text {th }}$ International Symposium on Agriculture, Osijek, Croatia, Proceedings, pp. 51-54.

9. Cotty, P.J., Jaime-Garcia, R. (2007). Influences of climate on aflatoxin producing fungi and aflatoxin contamination. International Journal of Food Microbiology, 119, 109-115.
10. Domsh, K.H., Gams, W., Anderson, T.H. (1980). Compendium of Soil Fungi. Academic Press, Subsidiary of Harcourt Brace Jovanovich Publishers, London.

11. Đisalov, J., Bodroža-Solarov, M., Bagi, F., Petrović, K., Ćulafić, J., Bočarov-Stančić, A., Brlek, T. (2015). First report of Alternaria tenuissima and Alternaria infectoria on organic spelt wheat in Serbia. Plant Disease (doi: http://dx.doi.org/10.1094/PDIS-11-141109-PDN).

12. Ellis, M.B. (1971). Dematiaceous Hyphomycetes. Commonwealth Mycological Institute, Kew, Surrey, England.

13. Fahrunnisa, M., Hashmi, H., Ghaffar, A. (2006). Seed-borne mycoflora of wheat, sorghum and barley. Pakistan Journal of Botany, 38 (1), 185-192.

14. Gibbson, J.G. (2012). The function and evolution of the Aspergillus genome. PhD Thesis, Vanderbilt University, Nashville, Tennessee.

15. Hedayati, M.T., Pasqualotto, A.C., Warn, P.A., Bowyer, P., Denning, D.W. (2007). Aspergillus flavus: human pathogen, allergen and mycotoxin producer. Microbiology, 153 (6), 1677-1692.

16. IARC, (2002). Monograph on the evaluation of carcinogenic risk to humans. World Health Organization, International Agency for Research on Cancer, Lyon, France, 82, 171.

17. Ivanović, M., Martić, M., Đurić, N., Dragović, G. (2001). The most common wheat disease in the conditions of Pančevački rit. Zbornik naučnih radova Instituta PKB Agroekonomik, 7, 27-31.

18. Janjić-Hajnal, E., Orčić, D., Torbica, A., Kos, J., Mastilović, J., Škrinjar, M. (2015). Alternaria toxins in wheat from the autonomous province of Vojvodina, Serbia: A preliminary survey. Food Additives and Contaminants, 32 (3), 361-370.

19. Kos, J., Škrinjar, M., Mandić, A., Mišan, A., Bursić, V., Šarić, B., Janić Hajnal, E. (2014). Presence of aflatoxins in cereals from Serbia. Food and Feed Research, 41(1), 31-38.

20. Krnjaja, V., Stanković, S., Lević, J. (2011). The presence of toxigenic Fusarium species and fusariotoxins deoxynivalenol and zeralenone in winter wheat. Biotechnology in Animal Husbandry, 27 (1), 63-73.

21. Kurovski, T.P., Wysocka, U. (2009). Fungi colonizing grain of winter spelt grown under two production systems. Phytopathologia, 54, 45-52.

22. Lacko-Bartošová, M., Korczyk-Szabó, J., Ražný, R. (2010). Triticum spelta - a speciality grain for ecological farming systems. Research Journal of Agricultural Sciences, 42, 143-147.

23. Lević, J., Gošić-Dondo, S., Ivanović, D., Stanković, S., Krnjaja, V., Bočarov-Stančić, A., Stepanić, A. (2013). An Outbreak of Aspergillus Species in Response to Environmental Conditions in Serbia. Pesticides and Phytomedicine, 28 (3), 167-179.

24. Lević, J., Stanković, S., Krnjaja, V., Bočarov-Stančić, A., Ivanović, D. (2012a). Distribution frequency and incidence of seed-borne pathogens of some cereals and industrial crops in Serbia. Pesticides and Phytomedicine, 27 (1), 33-40.

25. Lević, J., Stanković, S., Krnjaja, V., Tančić, S., Ivanović, D., Bočarov-Stančić, A. (2012b). Relationships of mycobiota on rachide and kernels of wheat. European Journal of Plant Pathology, 134, 249-256.

26. Nelson, P.E., Toussoun, T.A., Marasas, W.F.O. (1983). Fusarium Species. The Pennsylvania State University Press, University Park and London.

27. Nirenberg, H.I., O' Donnell, K. (1998). New Fusarium species and combinations within the Gibberella fujikuroi species complex. Mycologia, 90 (3), 434-458.

28. Oliveira, P.M., Zannini, E., Arendt, E.K. (2014). Cereal fungal infection, mycotoxins, and lactic acid bacteria mediated bioprotection: From crop farming to cereal products. Food Microbiology, 37, 78-95. 
29. Republic Hydrometeorological Service of Serbia (2015). Available from (http://www.hidmet.gov.rs/latin/meteorologija/klimatol ogija sredniaci.php/)

30. Rodrigues, P., Soares, C., Kozakiewicz, Z., Paterson, R.R.M., Lima, N., Venâncio, A. (2007). Identification and characterizatation of Aspergillus flavus and aflatoxins. Communicating Current Research and Educational Topics and Trends in Applied Microbiology, 527-534.

31. Samson, R.A., van Reenen-Hoekstra, E.S. (1988). Introduction to Foodborne Fungi. Centralbureau voor Schimmelcultures, Institute of the Royal Netherlands Academy of Art and Sciences, Baarn, Delft.

32. Solarska, E., Marzec, M., Kuzdraliński, A., Muszyńska, M. (2012). The occurrence of mycotoxins in organic spelt products. Journal of Plant Protection Research, 52(2), 190-195.

33. Stanković, S.Ž., Lević, J.T., Krnjaja, V.S., BočarovStančić, A.S., Tančić, S.L., Kovačević, T.M. (2007). Učestalost toksigenih vrsta Fusarium i fuzariotoksina u zrnu pšenice u Srbiji. Proceedings for Natural Sciences, Matica srpska Novi Sad, 113, 93-102.

34. Stojanović, T., Škrinjar, M., Psodorov, Đ. (2005a). Mycological and mycotoxicological quality of wheat and flour fractions. Proceedings for Natural Sciences, Matica srpska Novi Sad, 108, 37-42.
35. Stojanović, T., Škrinjar, M., Psodorov, Đ. (2005b). Fusarioses of wheat grain categories and their mycotoxicological infection. Proceedings for Natural Sciences, Matica srpska Novi Sad, 108, 43-50.

36. Suchowilska, E., Kandler, W., Sulyok, M., Wiwart, M., Krska, R. (2010). Mycotoxin profiles in the grain of Triticum monococcum, Triticum dicoccum and Triticum spelta after head infection with Fusarium culmorum. Journal of the Food Science and Agriculture, 90, 556-565

37. Šarić, M., Stojanović, T., Škrinjar, M., Menkovska, M. (2008). Effects of moulds on the safety and processing quality of Triticum aestivum. Proceedings for Natural Sciences, Matica srpska Novi Sad, 114, 105114.

38. Travassos, L.R., Lloyd., K.O. (1980). Sporotrix scenckii and related species of Ceratocysis. Microbiological Rewiews, 44 (4), 683-722.

39. Vučković, J., Bagi, F., Bodroža-Solarov, M., Stojšin, V., Budakov, D., Ugrenović, V., Aćimović, M. (2012). Alternaria spp. on spelt kernels (Triticum aestivum ssp. spelta). Plant Doctor, 1, 50-55.

40. Vučković, J., Bodroža-Solarov, M., Vujić, Đ., BočarovStančić, A., Bagi, F. (2013). The protective effect of hulls on the occurrence of Alternaria mycotoxins in spelt wheat. Journal of the Food Science and Agriculture, 93, 1996-2001.

\title{
МИКОБИОТЕ НА ЗРНУ ПШЕНИЦЕ (Triticum aestivum) И СПЕЛТЕ (Triticum aestivum spp. spelta) СА ПОДРУЧЈА ВОЈВОДИНЕ У 2015. гОдИни
}

\author{
Јелена А. Круљ ${ }^{1}$, Александра С. Бочаров Станчић ${ }^{2}$, Саша 3. Крстовић ${ }^{3}$, Игор М. Јајић ${ }^{3}$, Јована \\ С. Бркљача ${ }^{1}$ Ана М. Видаковић ${ }^{4}$, Марија И. Бодрожа Соларов ${ }^{1}$ \\ ${ }^{1}$ Универзитет у Новом Саду, Научни институт за прехрамбене технологије у Новом Саду, \\ 21000 Нови Сад, Булевар цара Лазара бр. 1, Србија \\ ${ }^{2}$ Институт за примену науке у пољопривреди, 11000 Београд, \\ Булевар деспота Стефрана 68Б, Србија \\ ${ }^{3}$ Универзитет у Новом Саду, Пољопривредни фракултет, 21000 Нови Сад, \\ Трг Доситеја Обрадовића 8, Србија \\ ${ }^{4}$ Универзитет у Новом Саду, Технолошки фракултет, 21000 Нови Сад, \\ Булевар цара Лазара 1, Србија
}

Сажетак: У раду је анализиран интензитет и учесталост микобиота на узорцима пшенице (Triticum aestivum) и спелте (Triticum aestivum ssp. spelta) сакупљених током жетве 2015. године. Резултати су показали да је више родова гљива изоловано са зрна конвенционалне пшенице у односу на спелта пшеницу. Најчешће изоловане врсте гљива са зрна пшенице припадале су роду Alternaria $(41,7 \%)$ и Fusarium $(15,2 \%)$, док је интензитет ових микобиота на зрну спелте износио $32,4 \%$ односно 10,4\%. Aspergillus flavus је идентифрикован на $40,0 \%$ узорака пшенице са интензитетом напада од $2,0 \%$. Такође, испитивање је вршено у циљу одређивања појаве и токсигеног потенцијала врсте A. flavus изолованих са ових стрних жита. За одређивање токсигеног профила изолата $A$. flavus примењена је једноставна тријажна метода. Резултати су указали на значај испитивања распрострањености микобиота на зрну пшенице и спелте, као и значај одређивања токсигеног потенцијала A. flavus.

Кључне речи: микобиоте, пшеница, спелта, Aspergillus flavus, токсигени потенцијал 